\title{
The Balanced Scorecard as a Potential Instrument for Supporting Planning and Improvement in Accounting Education: Comparative Survey Findings
}

\author{
C J Cronjé \\ School of Applied Accountancy University of South Africa \\ F N S Vermaak \\ Department of Financial Management University of Pretoria
}

\begin{abstract}
This paper is firstly a comparison of the components of a potential balanced scorecard for accounting departments of universities in South Africa and Australia. Secondly, the various suggested measurement criteria of the balanced scorecard components are also compared. The findings of the research paper indicate no significant differences. The conclusion is that the balanced scorecard constitutes a potential instrument for supporting the planning and improvement of the accounting education environment.
\end{abstract}

JEL I21, M41, 53

\section{1}

\section{Introduction}

As a result of inter alia the restructuring of higher education internationally (Bitzer, 2001: 139), universities all over the world face the challenge to continuously seek ways and methods to improve themselves in terms of equity, quality and cost-effectiveness. They need to become more transparent and accountable to stakeholders such as government, communities, parents, lecturers and students.

After 1980 various degrees of change occurred in higher-education systems worldwide (Bitzer, 2001: 149). These changes are shown in Table 1 below.

In view of becoming internationally comparable (Brand, 2001: 79), higher education in South Africa is also undergoing change, and only time will tell how radical this change has been.

\section{Table 1}

Indicative rates of change in national systems of higher education, post-1980

\begin{tabular}{|c|l|l|}
\hline Group & National system & Change \\
\hline 1 & Australia, United Kingdom & Extensive \\
\hline 2 & $\begin{array}{l}\text { Finland, The Netherlands, } \\
\text { Sweden, Belgium (Flemish- } \\
\text { speaking), Canada }\end{array}$ & Significant \\
\hline 3 & $\begin{array}{l}\text { Ireland, Spain, Belgium } \\
\text { (French-speaking), Malaysia, } \\
\text { United States }\end{array}$ & Moderate \\
\hline 4 & France, Germany, Italy, Japan & Limited \\
\hline
\end{tabular}

Source: Adapted from Farnham (1999)

This transformation requires higher-education systems to be characterised by excellence, relevance and cost-efficiency (Bitzer, 2001: 148). In addition to offering quality education (Gerwel, 1991: 123), universities worldwide should seek improvement from different perspectives, using different measures and criteria. 


\section{2}

\section{Review of the literature}

Financial accounting has traditionally been the primary way to measure business operations (Garrison, Noreen \& Seal, 2003). This approach might have been appropriate in an industrial age, when wealth was created through the conversion of labour, raw materials and capital. However, there is growing consensus in the new information era that financial indicators on their own (Peters \& Waterman, 1982; Fitzgerald, Johnston, Brignall, Silvestro \& Voss, 1993: 4; Bromwich \& Bhimani, 1994), however convincing in terms of their numerical precision (Edmonds, Edmonds and Tsay, 2000: 529), offer neither an adequate measure for competitiveness nor a guide to future performance.

Financial accounting measures by definition report on activities that have already occurred. This weakness means that the impact of decisions only become apparent after a significant time lag. These measures are therefore irrelevant when managers need guidance to improve current and future operations.

The pervasive attention to strategic issues in accounting and management (Simons 1995; Pearce \& Robinson, 2000) contributed to understanding that one-dimensional financial performance measures fail to indicate the importance of an organisation's relationship with its environment, and in particular with its customers. The need for a broader-based set of quantifiable performance measures (Parker, 1979; Ezzamel, 1992: 115; Drury, 2000: 923) is not new. Fitzgerald et al. (1993) for example put forward a performance model with six dimensions. Two of these performance dimensions, competitiveness and financial success are the results of strategy. The remaining four, namely quality, flexibility, resources utilisation and innovation, are the drivers of the success of that strategy. They conclude that the design of a balanced range of performance measures should be dependent upon the type of organisation, its competitive environment and chosen strategy.
Atkinson and McCrindell (1997) distinguish between primary goals that are externally oriented and concerned with measurable deliverables, and internally oriented secondary goals concerned with how services will be delivered. Emmanuel, Otley and Merchant (1990) similarly argue that organisational success is a multidimensional concept that changes both over time and between stakeholders.

The above examples show similarities to Kaplan and Norton's (1992) balanced scorecard which uses non-financial measures in addition to financial measures of performance.

The literature on the balanced scorecard dates back to the beginning of the previous decade when Kaplan and Norton (1992) developed the concept of the balanced scorecard. This concept focuses on the implications of financial accounting measures that lead to short-term decision making and under-investment in intangible assets such as employee skills and process innovation. Their conclusions were published in three articles (Kaplan \& Norton, 1992; Kaplan \& Norton, 1993; Kaplan \& Norton, 1996a), followed by a book (Kaplan \& Norton, 1996b).

The balanced scorecard was initially developed as a system for improved measurement. "The balanced scorecard forces managers to focus on the handful of measures that are most critical" (Kaplan \& Norton, 1992: 73). It guards against sub-optimal behaviour by forcing senior managers to consider all important operational measures as a whole. The set of performance measures is built around four perspectives that are equally important: finance, the customer, internal operations, and innovation and improvement activities. These four perspectives focus management's attention on the fact that an improvement in one area may have been achieved at the expense of another, or that an objective has not been met in a satisfactory manner.

In improving their performance measurement systems, many organisations adopt the early balanced scorecard concept that typically looks at strategy from the four perspectives indicated in Table 2. 
Table 2

Early balanced scorecard concepts

\begin{tabular}{|l|l|}
\hline Performance measure & Questions \\
\hline Finance & $\begin{array}{l}\text { What are our financial goals? } \\
\text { Has our financial performance improved? }\end{array}$ \\
\hline Customer & $\begin{array}{l}\text { Which customers do we want to serve and how are we going to win and retain them? } \\
\text { Do customers recognise that we are delivering more value? }\end{array}$ \\
\hline $\begin{array}{l}\text { Internal business } \\
\text { processes }\end{array}$ & $\begin{array}{l}\text { Have we improved our key business processes so that we can deliver more value } \\
\text { to our customers? } \\
\text { Which internal business processes are critical to providing value to our customers? }\end{array}$ \\
\hline Learning and growth & Are we maintaining our ability to change and improve? \\
\hline
\end{tabular}

Source: Adapted from Kaplan and Norton, 1996 and Garrison et al., 2003

The emphasis in Table 2 is on improvement. The attainment of a specific goal such as a profit of $\mathrm{Rx}$, is put in perspective as part of a continuous improvement process.

The balanced scorecard provides the following benefits, as experienced by many organisations (Kaplan \& Norton, 1996b; Garrison et al., 2003: 695):

- It makes strategy operational by translating strategy into performance measures and goals.

- It helps focus the entire organisation on what must be done to create breakthrough performance.

- It acts as an integrating device, an umbrella, for a variety of diverse, often disconnected corporate programmes such as quality, reengineering, process redesign and customer service.

- Corporate-level measures can be broken down so that local managers, operators and employees can see what they have to do well to improve their organisational effectiveness.

- It provides a comprehensive view that overturns the traditional idea of the organisation as a collection of isolated, independent functions and departments.

The above benefits show that the balanced scorecard creates a shared understanding of an organisation's goals and what is required to achieve these goals, and it helps the organisation to focus on what it has to do well.
The use of the balanced scorecard has been extended and it is now used as the basis of an integrated strategic management system (Kaplan \& Norton, 1996a; Anon, 2003). Nowadays organisations use the balanced scorecard to:

- Clarify and update strategy.

- Communicate strategy throughout the organisation.

- Align unit and individual objectives with the strategy.

- Link strategic targets to long-term objectives and annual budgets.

- Identify and align strategic initiatives.

- Conduct periodic performance reviews to learn about and improve strategy.

Here the balanced scorecard corresponds with a more sophisticated view of strategy as a developing process (Simons, 1995), where the organisation is engaged in a learning process both through internal communication and through contact with its customers and suppliers. It centralises feedback on strategy and continually tests the theories underlying that strategy.

\section{3}

\section{The Balanced Scorecard in not-for-profit organisations}

As indicated above, research in this field focused on for-profit organisations. The research results show that the balanced 
scorecard is a management accounting instrument to apply strategy by balancing traditional financial and contemporary nonfinancial performance measures for decision making.

Less, although important, research has been done in the non-profit sector, for example in the local government sectors. These entities began to use the balanced scorecard due to fiscal pressure, a drive for reform, and an increasing demand for accountability from stakeholders such as the taxpayer.
Some research has been done in academic departments at universities. (refer to Vermaak \& Cronjé, 2001: 302 for an analysis of this research.) The results of their research indicate that the balanced scorecard contains possibilities that supplement existing tools and that the instrument could support planning and improvement of the accounting education environment. The framework reflected in Table 3 was used to guide their research.

Table 3

Components for inclusion in a department's potential balanced scorecard

\begin{tabular}{|l|l|}
\hline Component & \\
\hline Financial perspective & How do we create value for our stakeholders? \\
\hline Customer perspective & What do existing and new customers value from us? \\
\hline $\begin{array}{l}\text { Internal business } \\
\text { perspective }\end{array}$ & $\begin{array}{l}\text { Which processes must we excel at to achieve our financial and customer } \\
\text { objectives? }\end{array}$ \\
\hline $\begin{array}{l}\text { Innovation and learning } \\
\text { perspective }\end{array}$ & Can we continue to improve and create future value? \\
\hline
\end{tabular}

It has been reported that the school of accounting and law at the Royal Melbourne Institute of Technology University has decided to use the balanced scorecard for performance management (Watty, 2001: 44).

\section{4 Research questions}

Two questions directed the research based on the framework described in Table 2 and Table 3. First: To what degree can the components of a potential balanced scorecard for an accounting department at a South African university be compared with the components of a potential balanced scorecard for an accounting department at an Australian university? Second: How do the suggested measures of the four balanced scorecard perspectives in an accounting education environment at a South African university compare with those at Australian universities?

\section{5 Research methodology}

Questionnaires were e-mailed to compare the research findings on preferable balanced scorecard measures pertaining to accounting departments at South African universities with those preferred by Australian universities. The measures used in the e-mail survey were based on the findings of the studies of Chang and Chow (1999) and O’Neil, Bensimon, Diamond and Moore (1999).

The questionnaires were distributed in August 2001 to the heads of 19 accounting departments at South African universities, and in January 2003 to the heads of 16 accounting departments at Australian universities. The time lapse has no significance influence on the comparability of the results since no major changes occurred during that time. This survey is restricted to South African universities as defined before 2004, as the former technikons are now also listed as universities of technology.

The purpose and principles of the balanced scorecard were set out on the cover page of the 
questionnaire. The next page described the objective of the survey and dealt with background information, for example the province / region, the courses presented by every financial accounting department, the number of students registered for the different financial accounting courses, and the number of lecturers responsible for presenting the courses in the financial accounting departments.

The next page presented the four components of a potential balanced scorecard for an accounting department (see Table 3). The respondents were requested to indicate on a scale of 1 to 5 (with $1=$ strongly disagree and $5=$ strongly agree) whether they considered each of these components suitable for inclusion in their department's potential balanced scorecard. They also had to indicate on a scale from 1 to 5 and in accordance with a list of goals and corresponding measures (see Table 4), which of the options best represented their evaluation of every component listed in the questionnaire.

\section{Table 4}

Suggested balanced scorecard measures

\begin{tabular}{|c|c|}
\hline \multicolumn{2}{|c|}{ Component 1: Financial perspective: How do we create value for our stakeholders? } \\
\hline Goals & Measures \\
\hline \multirow[t]{3}{*}{ Prosper } & Annual subsidy to department \\
\hline & Amount of outside funds \\
\hline & Amount of donations \\
\hline \multirow[t]{2}{*}{ Succeed } & Enrolment trend \\
\hline & Test / examination scores \\
\hline \multirow[t]{2}{*}{ Survive } & Extent of student enrolment \\
\hline & Funding per student \\
\hline \multicolumn{2}{|c|}{ Component 2: Customer perspective: What do existing and new customers value from us? } \\
\hline Goals & Measures \\
\hline \multirow[t]{3}{*}{ Effective student placement } & Percentage students with job offers at graduation \\
\hline & Number of organisations recruiting on campus \\
\hline & Average starting salaries of graduates \\
\hline \multirow[t]{3}{*}{ Quality instruction } & Alumni evaluation \\
\hline & Accreditation \\
\hline & Professional examination pass rate \\
\hline Highly valued programmes & Percentage enrolment out of applications \\
\hline Quality academic advice & Student evaluation of services / advisory service \\
\hline \multirow[t]{2}{*}{ Flexible course schedules } & Student satisfaction survey \\
\hline & Frequency of required courses \\
\hline \multicolumn{2}{|c|}{$\begin{array}{l}\text { Component 3: Internal business perspective: Which processes must we excel at to achieve our financial and } \\
\text { customer objectives? }\end{array}$} \\
\hline Goals & Measures \\
\hline Quality assurance & Evaluation of student competence \\
\hline \multirow[t]{2}{*}{ Internship } & Number of internship opportunities available \\
\hline & Number of organisations involved \\
\hline
\end{tabular}




\begin{tabular}{|c|c|}
\hline & Student evaluation \\
\hline \multirow[t]{2}{*}{ Cost-efficiency } & Faculty-to-student ratio \\
\hline & Education expenses per student \\
\hline \multirow[t]{2}{*}{ Optimal class size } & Average class size for majors \\
\hline & Average class size compared to that of other institutions \\
\hline Unique or specialised curriculum & Number of other departments offering same programme \\
\hline \multicolumn{2}{|c|}{ Component 4: Innovation and learning perspective: Can we continue to improve and create future value? } \\
\hline Goals & Measures \\
\hline \multirow[t]{4}{*}{ Department's professional growth } & Number of departmental presentations at conferences \\
\hline & Number of departmental publications \\
\hline & Number of seminars attended by department \\
\hline & Travel budget for conference attendance \\
\hline New technology in teaching & Number of courses incorporating new technology \\
\hline \multirow[t]{2}{*}{ Innovation in teaching } & Number of teaching innovation projects \\
\hline & Number of teaching workshops attended by department \\
\hline \multirow[t]{2}{*}{ Curriculum innovation } & Number of curriculum revisions in last five years \\
\hline & Number of new courses offered in last five years \\
\hline \multirow{2}{*}{$\begin{array}{l}\text { Partnering with accounting/business } \\
\text { organisations }\end{array}$} & Number of organisations involved in joint activities \\
\hline & Number of joint activities \\
\hline
\end{tabular}

The respondents were also invited to make changes or add suggestions to the components presented in the questionnaire.

In the South African survey 58 per cent (11) of the questionnaires were returned. No followup was considered necessary due to the high response rate. However, only 44 per cent (7) of the questionnaires in the Australian survey were returned. Follow-up efforts proved unsuccessful. This response rate was not considered a problem as the results were interpreted qualitatively rather than quantitatively.

\section{6}

\section{Comparative survey results}

This section presents the comparative survey results in five tables. The first, Table 5, covers the percentages for the scale of responses given to each balanced scorecard component. The second, Table 6, indicates the financial performance measures that motivate heads of departments to consider how their stakeholders perceive their departments. In tertiary institutions the "stakeholder" concept becomes problematic because of diverse groups who often have different interests, for example the government that provides funding and a legislative framework for the university's operations, students and parents, alumni and lecturers. The third, Table 7, deals with the measures that encourage heads of departments to consider how the customers perceive their departments. The fourth, Table 8, contains results that have a bearing on encouraging heads of departments to improve their internal processes to ensure customer satisfaction. The fifth, Table 9, presents results regarding learning and growth as heads of departments were requested to consider what would be required to meet their goals in terms of financial, customer and internal business perspectives. 
Balanced scorecard components

\begin{tabular}{|c|c|c|c|c|c|c|c|c|}
\hline \multirow[b]{3}{*}{ Scale } & \multicolumn{8}{|c|}{$\begin{array}{c}\text { Table } \mathbf{5} \\
\text { Percentages per component }\end{array}$} \\
\hline & \multicolumn{2}{|c|}{ Financial } & \multicolumn{2}{|c|}{ Customer } & \multicolumn{2}{|c|}{ Internal business } & \multicolumn{2}{|c|}{$\begin{array}{l}\text { Innovation and } \\
\text { learning }\end{array}$} \\
\hline & South Africa & Australia & South Africa & Australia & South Africa & Australia & South Africa & Australia \\
\hline 1 & - & 25 & - & - & - & - & - & - \\
\hline 2 & - & - & - & - & - & - & - & - \\
\hline 3 & 18 & 25 & - & - & 9 & - & - & - \\
\hline 4 & 27 & 50 & 18 & 25 & 36 & 50 & 46 & 25 \\
\hline 5 & 55 & - & 83 & 75 & 55 & 50 & 55 & 75 \\
\hline
\end{tabular}

More than half (55 per cent) of the respondents for South Africa (SA) indicated that they strongly agreed on every component. However, the respondents for Australia (AUS) indicated no strong agreement when it came to the financial component.

The two components on which the South African respondents fully agreed (scales 4 and 5) were "customer" and "innovation and learning”. The Australian respondents fully agreed on the "customer", "internal business", and "innovation and learning" perspectives.

The South African respondents indicated a measure of uncertainty about the financial perspective (18.2 per cent on scale 3 ). This is not unusual, since this perspective usually gets less attention at academic institutions than other measures. None of the respondents indicated a 1 or a 2 on the given scale, which implies that the heads of departments were quite positive about the balanced scorecard's potential to benefit their departments. The Australian respondents seemed to place less emphasis on the financial component of the balanced scorecard's potential to benefit their departments $(25$ per cent on scale 1 , and 0 per cent on scale 5).

The respondents made a total of eight changes / suggestions. The changes/suggestions of the South African respondents only dealt with a better definition of the component itself, which had no fundamental effect on the existing designation of the component. The Australian respondents emphasised quality improvement for all aspects.

With regard to Tables 6 to 9, only those aspects the respondents marked with a 4 or a 5 on the given scale were shown. Four respondents made suggestions with regard to further goals and measures (not brought into account here).

8

\section{Financial perspective}

Table 6

Component 1: How do we create value for our stakeholders?

\begin{tabular}{|l|l|c|c|}
\hline Goals & Measures & SA (\%) & AUS (\%) \\
\hline Prosper & Annual subsidy to department & 46 & 25 \\
\hline & Amount of donations & 55 & 25 \\
\hline & Amount of outside funds & 73 & 75 \\
\hline Succeed & Test/examination scores & 73 & 75 \\
\hline
\end{tabular}




\begin{tabular}{|l|l|c|c|}
\hline & Enrolment trend & 91 & 100 \\
\hline Survive & Funding per student & 73 & 75 \\
\hline & Extent of student enrolment & 91 & 100 \\
\hline Average & 72 & 68 \\
\hline
\end{tabular}

There are similarities between the South African and Australian ratings of the measures. Both placed considerable emphasis on the measures "enrolment trend" and "extent of student enrolment" as indicators of stakeholder value.

The measures "amount of outside funds", "test/examination scores" and "funding per student" received scores of 73 per cent (SA) and 75 per cent (AUS), indicating high correlation. The majority of respondents (91 per cent for SA and 100 per cent for AUS) indicated "enrolment trend" and "extent of student enrolment" as the two measures that would best measure financial success. With respect to measuring the creation of value for stakeholders, scores of 73 per cent (SA) and 75 per cent (AUS) were allocated to each of "test/ examination scores", "amount of outside funds" and "funding per student". These scores could indicate that the heads of accounting departments do not consider education outcomes and funds as the most important measures.

Both countries listed "annual subsidy to the department" and "amount of donations" (measures which the department's input does not directly influence) as being of less importance. The measures Table 6 reflect as the most important indicate an emphasis on the objectives of success and survival.

\section{Customer perspective}

\section{Table 7}

Component 2: What do existing and new customers value from us?

\begin{tabular}{|l|l|c|c|}
\hline Goals & Measures & SA (\%) & AUS (\%) \\
\hline $\begin{array}{l}\text { Effective student } \\
\text { placement }\end{array}$ & Percentage students with job offers at graduation & 55 & 100 \\
\hline & Number of organisations recruiting on campus & 55 & 100 \\
\hline & Average starting salaries of graduates & 64 & 75 \\
\hline Quality instruction & Alumni evaluation & 64 & 50 \\
\hline & Professional examination pass rate & 91 & 75 \\
\hline $\begin{array}{l}\text { Highly valued } \\
\text { programmes }\end{array}$ & Accreditation & 100 & 100 \\
\hline $\begin{array}{l}\text { Quality academic } \\
\text { advice }\end{array}$ & Student evaluation of services/advisory service & 36 & 25 \\
\hline $\begin{array}{l}\text { Flexible course } \\
\text { schedules }\end{array}$ & Student satisfaction survey & 82 & 100 \\
\hline & & 82 & 100 \\
\hline Average & Frequency of required courses & 82 & 75 \\
\hline
\end{tabular}


The South African and Australian respondents indicated "accreditation" (100 per cent in both cases) as the measure that both existing and new customers would value most. The South African respondents valued "professional examination pass rate" as a measure (91 per cent), but it was less important to the Australians (75 per cent). Three other measures, "student evaluation of services/advisory service", "student satisfaction survey" and the "frequency of required courses" also received substantial support from the South African respondents. The Australians allocated full scores to the "percentage students with job offers at graduation", the "number of companies recruiting on campus", "student evaluation of services/advisory service", and "student satisfaction survey". Both countries considered "percentage enrolment out of applications" as the weakest measure of programme value.

Interestingly, only one respondent identified and recorded staff as a customer class, even though a case can be made that the faculty and staff could affect service to the other customer classes.

"Quality instruction" as a goal was highly valued by the South Africans in the selection of the above-mentioned measures. However, the Australian respondents rated this aspect lower and placed greater emphasis on the "quality of academic advice".

10

\section{Internal business perspective}

Table 8

Component 3: Which processes must we excel at to achieve our financial and customer objectives?

\begin{tabular}{|l|l|c|c|}
\hline Goals & Measures & SA (\%) & AUS (\%) \\
\hline Quality assurance & Evaluation of student competence & 91 & 100 \\
\hline Internship & Student evaluation & 36 & 100 \\
\hline & Number of organisations involved & 46 & 100 \\
\hline & Number of internship opportunities available & 51 & 50 \\
\hline Cost-efficiency & Faculty-to-student ratio & 64 & 100 \\
\hline & Education expenses per student & 73 & 25 \\
\hline Optimal class size & Average class size compared to that of other institutions & 36 & 75 \\
\hline & Average class size for majors & 73 & 75 \\
\hline $\begin{array}{l}\text { Unique or } \\
\text { specialised } \\
\text { curriculum }\end{array}$ & Number of other departments offering the same programme & 55 & 50 \\
\hline Average & & 58 & 75 \\
\hline
\end{tabular}

The "evaluation of student competence" was indicated (91 per cent for SA, 100 per cent for Aus) as the best measure of internal systems.

Three measures, "student evaluation" (36 per cent), "average class size compared to that of other institutions" (36 per cent) and "number of organisations involved" (45 per cent), were considered of little value in South Africa, whereas the Australian respondents considered these three measures to be highly valuable. A possible reason for the difference of opinion could be that no individual department controlled a university's internal business processes. 
Innovation and learning perspective

\begin{tabular}{|c|c|c|c|}
\hline \multicolumn{4}{|c|}{$\begin{array}{l}\text { Table } 9 \\
\text { inue to improve and create future value? }\end{array}$} \\
\hline Goals & Measures & SA (\%) & AUS (\%) \\
\hline \multirow{4}{*}{$\begin{array}{l}\text { Dept's professional } \\
\text { growth }\end{array}$} & Travel budget for conference attendance & 55 & 100 \\
\hline & Number of departmental presentations at conferences & 73 & 100 \\
\hline & Number of seminars attended by department & 73 & 100 \\
\hline & Number of departmental publications & 82 & 100 \\
\hline $\begin{array}{l}\text { New technology } \\
\text { in teaching }\end{array}$ & Number of courses incorporating new technology & 82 & 75 \\
\hline \multirow[t]{2}{*}{ Innovation in teaching } & Number of teaching workshops attended by department & 46 & 50 \\
\hline & Number of teaching innovation projects & 82 & 100 \\
\hline \multirow[t]{2}{*}{ Curriculum innovation } & Number of curriculum revisions in last five years & 64 & 100 \\
\hline & Number of new courses offered in last five years & 64 & 100 \\
\hline \multirow{2}{*}{$\begin{array}{l}\text { Partnering with } \\
\text { accounting/business } \\
\text { organisations }\end{array}$} & Number of joint activities & 55 & 50 \\
\hline & Number of organisations involved in joint activities & 64 & 75 \\
\hline Average & & 67 & 86 \\
\hline
\end{tabular}

The respondents for both countries considered five measures to be especially useful in monitoring innovation and learning: "number of departmental presentations at conferences", "number of seminars attended by department", "number of departmental publications", "number of courses incorporating new technology" and "number of teaching innovation projects". The Australian respondents indicated "department's professional growth" and "curriculum innovation" as important goals in this regard.

It is evident from the above research results that the heads of departments in both South Africa and Australia consider some measures more important than others. However, tables 6 to 9 show that a wide variety of measures can be used to construct the balanced scorecard for an accounting department.

According to Table 5 the respondents were requested to consider four labelled components as a given and to indicate whether they would consider these components suitable for inclusion in a balanced scorecard for their departments. The South African respondents rated the customer component as the most important, and the Australian respondents considered the customer, learning and growth components to be of great value.

Table 10 below offers a summary of the averages for these components and their measures from tables 6 to 9 . Table 10 indicates the weights the components received after the respondents had access to the measures for each component, and shows a different emphasis by the South African respondents from the assessments reflected in Table 5. Table 10 indicates no difference in the Australian ratings, whereas the South African respondents have replaced the customer component with the financial component. 
Table 10

Component comparison - averages

\begin{tabular}{|l|c|c|}
\hline & SA (\%) & AUS (\%) \\
\hline Financial & 72 & 68 \\
\hline Customer & 71 & 80 \\
\hline Internal business processes & 58 & 75 \\
\hline Learning and growth & 67 & 86 \\
\hline
\end{tabular}

Based on the information in Table 10, there seems to be no consistent ranking for the components in the balanced scorecard. The sequence of the components used in Tables 6 to 9 is therefore the same as that used by Kaplan and Norton (1996b).

\section{2}

\section{Conclusion}

This study contributed insights into the similarities and differences in respect of the components and suggested measures of a potential balanced scorecard for accounting departments. The results of the research indicate that the balanced scorecard contains possibilities that could supplement existing tools. The heads of accounting departments included in our survey indicated that they were reasonably positive about the potential benefits of the balanced scorecard in the accounting education environment.

By comparison, the South African universities rated the "customer" component as more important, while the Australian universities placed more emphasis on the "customer" and "learning and growth" components.

In most cases the universities in South Africa and Australia agreed with the measures that were provided. It would therefore be meaningful to include these measures in constructing an effective balanced scorecard for an accounting department.

The research has shown no significant differences in the development of a balanced scorecard as a potential instrument for supporting planning and improvement in accounting education in both South Africa and Australia.

\section{References}

1 ANONYMOUS (2003) "Balanced Scorecards give performance and change management a very timely boost”, Pay for Performance Report, 3(2): 4-7. http://search.epnet.com/ direct.asp? an $=8952041 \& \mathrm{db}=$ buh.

2 ATKINSON, A.A. \& MCCRINDELL, J.Q. (1997) "Strategic performance measurement in government”, CMA Management, 71(3): 20-23.

3 BITZER, E. (2001) "Shaping and sizing: proposed transformations of the higher education landscape in South Africa", Democratic Transformation of Education in South Africa, Seminar Report: 139-52. Konrad-AdenaurStiftung: Johannesburg.

4 BRAND, H. (2001) "Quality indicators for South African schools against the background of international practices", Democratic Transformation of Education in South Africa, Seminar Report: 79-87, Konrad-Adenaur-Stiftung: Johannesburg.

5 BROMWICH, M. \& BHIMANI, A. (1994) Management Accounting: Pathways to Progress, CIMA: London.

6 CHANG, O.H. \& CHOW, C.W. (1999) "The Balanced Scorecard: A potential tool for supporting change and continuous improvement in accounting education", Issues in Accounting Education, 14(3): 395-412.

7 DRURY, C. (2000) Management and Cost Accounting, Business Press: London.

8 EDMONDS, T.P., EDMONDS, C.D. \& TSAY, B. (2000) Managerial accounting concepts, Irwin McGraw-Hill: Boston.

9 EMMANUEL, C., OTLEY. D. \& MERCHANT K. (1990) Accounting for Management Control, Thomson Business Press: London.

10 EZZAMEL, M. (1992) Business Unit and Divisional Performance Measurement, Academic Press: London.

11 FARNHAM, D. (ed.) (1999) "Managing academic staff in changing university systems, international trends and comparisons" The Society for Research into Higher Education, Open University Press: Buckingham.

12 FITZGERALD, L.; JOHNSTON, R.; BRIGNALL, T.J.; SILVESTRO, R. \& VOSS, C. (1993) Performance Measurement in Service Businesses, CIMA: London.

13 GARRISON, R.H., NOREEN, E.W. \& SEAL, W. (2003) Management accounting (European ed.) McGraw-Hill: Berkshire. 
14 GERWEL, J. (1991) "Transformation and the universities: The experience of the University of the Western Cape", Education in a Future South Africa, Policy Issues for Transformation, Unterhalter, E., Wolpe, H. \& Botha, T. (eds.): 123-35.

15 KAPLAN, R.S. \& NORTON, D.P. (1992) "The balanced scorecard - Measures that drive performance", Harvard Business Review, 70(1): 71-79.

16 KAPLAN, R.S. \& NORTON, D.P. (1993) "Putting the balanced scorecard to work", Harvard Business Review, 71(5): 134-42.

17 KAPLAN, R.S. \& NORTON, D.P. (1996a) "Using the balanced scorecard as a strategic management system", Harvard Business Review, 70(1): 75-85.

18 KAPLAN, R.S. \& NORTON, D.P. (1996b) The Balanced Scorecard: Translating Strategy into Action, Harvard Business School Press: Boston.

19 O'NEIL, H.F. BENSIMON, E.M. DIAMOND, M.A. \& MOORE, M.R. (1999) "Designing and implementing an academic scorecard", Change, 31(6): 33-40.
20 PARKER, L.D. (1979) "Divisional performance measurement: Beyond an exclusive profit test", Accounting and Business Research, 9(36): 30919.

21 PEARCE, J.A. \& ROBINSON, R.B. (2000) Strategic Management, Formulation, Implementation, and Control, Irwin McGrawHill: Boston.

22 PETERS, T. \& WATERMAN, R. (1982) In Search of Excellence, Harper Row.

23 SIMONS, R. (1995) Levers of Control, Harvard Business School: Boston.

24 VERMAAK, F.N.S. \& CRONJE, C.J. (2001) "The Balanced Scorecard as a potential instrument for supporting the planning and improvement of accounting education in South Africa", Meditari Accounting Research, 9: 30112.

25 WATTY, K. (2001) "Getting on the act", Australian CPA, 71(5). 